\title{
STUDI KARAKTERISTIK TRANSPORTASI \\ ANGKUTAN JALAN DENGAN PENYEBERANGAN
}

EDDI Amd MM'1)

Dosen STTD

jl Raya Setu 89 cibuntu Bekasi

BAMBANG.MT ${ }^{3)}$

Dosen STTD

jl Raya Setu 89 cibuntu Bekasi
CHAIRUL INSANI ATD.MM²)

Dosen STTD

jl Raya Setu 89 cibuntu Bekasi

\author{
PURBOYO.MSI ${ }^{4)}$ \\ Dosen STTD \\ Jl Raya Setu 89 cibuntu Bekasi
}

\begin{abstract}
ION
Prajen-Palembang Ilir rute,Its has increasing trend to demand of transport which is giving imfact to services of road transport, so its to be occurred traffic jam.Eitherwise give traffic assignment of the route to be more complicated.for instance in plaju terminal and Mariana market.Poltek trans SDP Palembang had planned to build Port Ferrys Laboratory where its could be using to transfer passenger and goods from Prajen to Palembang Ilir.

The result of research produce in 2019 that travel time ratio are 307 percent private cars and 325 percent for public taransport better than existing services.And Trip Cost Ratio(TCR) are 125 percent for private and public transport were better than existing.
\end{abstract}

Key words:Ferrys,road,rute,time,ratio,cost,trip and services.

\section{ABSTRAKSI}

Lintas Prajen- Palembang ilir, semakin hari mempunyai kecenderungan yang semakin meningkat dan hal ini memberikan dampak kepada kelancaran pelayanan jasa angkutan jalan pada lintas tersebut yan $g$ sering mengalami kemacetan dan dampak lain dari tingginya volume lalu lintas tersebut turut pula membebani jaringan transportasi jalan di Terminal Plaju dan Pasar Mariana yang sudah mulai jenuh dan dilain pihak ada rencana dari Poltek trans SDP Palembang membangun Lab. Pelabuhan penyeberangan.

Upaya mencarikan lintas alternatif dengan ide memanfaatkan angkutan sungai musi dari Prajen Banyuasin ke Palembang ilir (Sungai lais, Sako kenten, Lemabang), perlu dilakukan justifikasi secara ilmiah mengenai prospek kedepannya, dengan mengkaji faktor karaktristik system transportasi dengan tolok ukur Rasio Waktu Perjalanan (RWP) dan 
Rasio Biaya Perjalanan (RBP). Setelah dikaji secara ilmiah dari jumlah perjalanan kendaraan Angkutan jalan umum pada tahun 2019, dengan sampel 3 persen yang dikerjakan oleh 15 orang surveyor didapatkan RWP untuk angkutan jalan lebih besar 307 persen untuk public transport persen dan 3,25 persen private cars bila dibandingkan penyeberangan. Sedangkan rasio biaya perjalanan (RBP) menghasilkan tingkat efektifitas angkutan jalan lebih lemah dari angkutan sungai dimana angkutan jalan lebih boros 25 persen, dari hasil pengkajian akan didapatkan nilai $R W P$ dan RBP secara ilmiah yang menjelaskan bahwa lintas angkutan sungai lebih baik bila dibandingkan dengan lintas angkutan jalan. Dengan metode kajian yang cukup sederhana dan memanfaatkan data serta kesempatan yang ada, seyogyanya akan dapat membantu pemerintah untuk memberikan solusi lalu lintas angkutan orang dari dan ke Palembang ilir kedaerah Prajen/mariana.

Kata Kunci : Penyeberangan, jalan, Lintas, Waktu, perjalanan, Biaya. Pelayanan, kendaraan.

\subsection{LATAR BELAKANG}

Daerah sungai lais dan Sako kenten dan Prajen/ mariana mempunyai daya magnet keterkaitan antara satu sama lain, utamanya dalam kegiatan bekerja dan kebutuhan sehari hari, untuk menjembatani kegiatan dimaksud saat ini dilayani oleh angkutan umum jalan raya atau dilayani oleh angkot( angkutan Kota),serta juga dilayani oleh angkutan pribadi seperti mobil motor dan pula angkutan barang

Transportasi dari wilayah Kab. Banyuasin ( kec. Mariana,Cinta Manis, Muara Kumbang,dan Air Sugihan) termasuk desa prajen dan mariana akan melintasi jalan sabar jaya menuju Palembang ilir Seperti pada gambar 1 merupakan implikasi dari kebutuhan masyarakat untuk bekerja dan perdagangan serta kegiatan sekolah yang dilakukan secara rutin . Disamping juga ada angkutan umum yang hingga saat ini dilayani oleh angkutan kota dan perkotaan yang terdiri atas 2(dua) trayek yakni (lihat gambar1.1) :

Pertama: Lintas Prajen - Plaju.

Kedua : Lintas Plaju-Ke Palembang ilir. 
Gambar 1.1

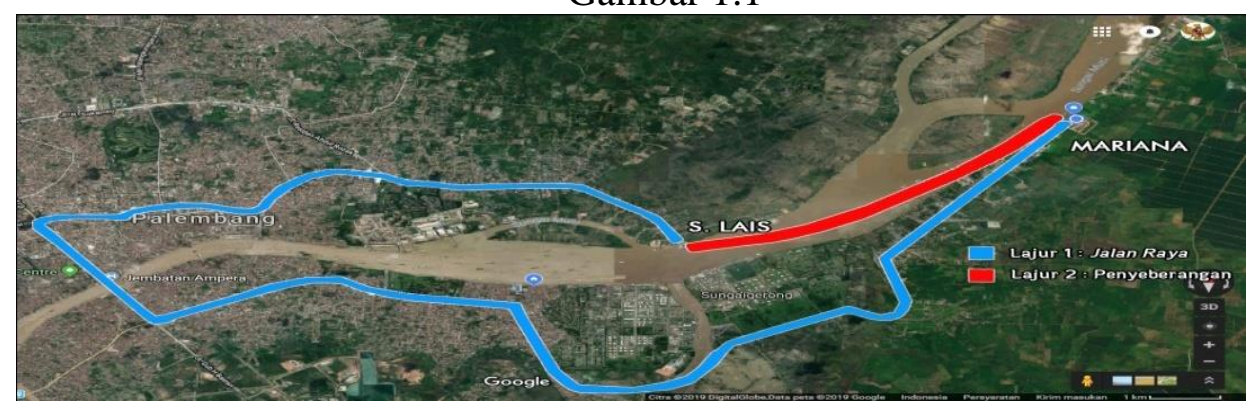

Dilain pihak ada rencana dari Politeknik Transportasi Sungai dan Penyeberangan (Poltek Trans SDP Palembang) untuk membangun Lab Praktek pelabuhan penyeberangan dengan maket seperti pada Gambar 1.2

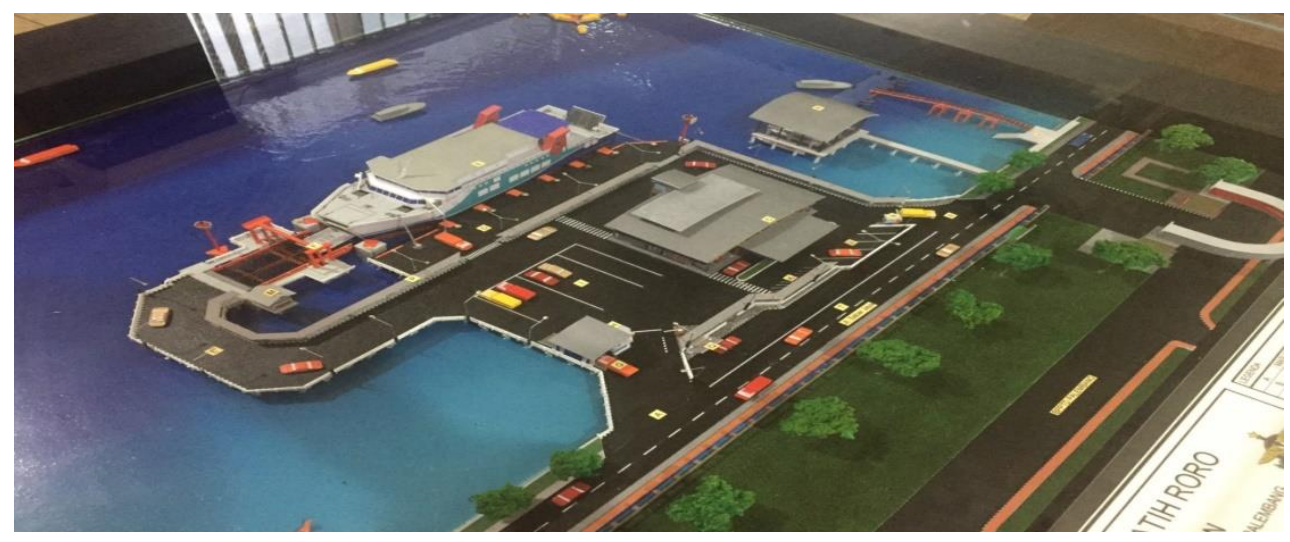

Jika pembangunan Pelabuhan ini terealisasi pada DIPA tahun 2021 , maka penelitian ini dimaksud kan untuk dipakai sebagai alternative untuk penyeberangnan ke Palembang bagian ilir yang merupakan tujuan perjalanan atau sebaliknya dari ke empat kecamatan banyuasin yang tersebut diatas mengingat azas manfaat selain digunakan sebagi praktek yang juga dapat merupakan ajang praktek riil bagi taruna teantang operasi angkutan sungai dan penyeberangan yang pengopersaiannya dapat menggunakan pihak ketiga

\subsection{RUMUSAN MASALAH}

Permasalahan pokok dalam penelitian ini adalah membandingkan lintas angkutan jalan yang menuju Palembang Ilir dengan alternative penyeberangn prajen -Palembang ilir perbandingan ini perlu suatu penilaian lintasan manakah yang lebih menguntungkan dari aspek karaekteristik transportasi dan kondisi lalu lintas angkutan jalan semakin lama semakin rendah tingkat

Perhitungan lalu lintas dilakukan pada studi ini tahun 2017 pada Cordon Ruas jalan di PerbatasanKenten Laut - MUBA, Ruas jalan di Perbatasan Alang Alang Lebar Banyuasin, Ruas Jalan diPerbatasan Palembang - Indralaya, dan Ruas Jalan di Perbatasan 
Plaju - Mariana (Sungai Rebo). Pada tahun 2016, dilakukan kerjasama Unsri dan Bappeda dalam kajian "Survei Satuan MobilPenumpang / Lalu Lintas Harian Rata-Rata Kota Palembang”. Survei pada ruas jalan dilakukan di11 ruas jalan utama di kota Palembang. Meliputi ruas Jalan H.M. Ryacudu (Ampera), Jalan Jend.Sudirman antara Bundaran Air Mancur dan Pasar Cinde, Jalan Jend. Sudirman antara Charitas danPOLDA, Jalan Demang Lebar Daun, Jalan A. Yani, Jalan Basuki Rahmat, Jalan Veteran, JalanKol. Atmo, Jalan Kapten A. Rivai, Jalan Merdeka, dan Jalan Abdul Rozak.Untuk melihat kondisi lalu lintas saat ini dan dimasa mendatang, dilakukan prediksi dengan modeltransportasi yang dikembangkan menggunakan JICA Strada yang biasa digunakan untukmemodelkan kotakota di negara berkembang seperti Palembang.Langkah awal yang dilakukan adalah menguji keandalan model dengan menggunakan data trafficcount yang telah dilakukan, kemudian dilakukan analisa pada beberapa kondisi lalu lintas baikuntuk saat ini maupun 5 tahun mendatang didapatkan level of service pada lintas jalan A yani dan plaju mariana/prajen dengan kategori E $(0,90)$ yang berarti tingkat kepadatan lalinnya sangat tinggi, oleh karenanya perlu ada alternative lintas atau moda angkutan lain.

\section{. Pola Perjalanan di kota Palembang tahun 2017}

Analisa terhadap pola perjalanan ini adalah untuk mengetahui besaran perjalanan dari dan ke masing-masing kecamatan yang ada di kota Palembang di tahun 2017. Kebanyakan orang

memerlukan perjalanan untuk mencapai tempat-tempat tujuan bekerja, bersekolah atau ke tempat tempatpendidikan yang lain, berbelanja, ke tempat-tempat pelayanan, mengambil bagian dalamberbagai kegiatan sosial dan bersantai di luar rumah, serta banyak tujuan yang lain.Hal yang utama dalam masalah perjalanan adalah adanya hubungan antara tempat asal dan tujuan,yang memperlihatkan adanya lintasan, alat angkut (kendaraan) dan kecepatan. Pola perjalanan didaerah perkotaan dipengaruhi oleh tata letak pusat-pusat kegiatan di perkotaan (permukiman, perbelanjaan, perkantoran, sekolah, rumah sakit, dan lain-lain).

\section{LANDASAN TEORI.}

Uji hipotesis dan signifikansi, atau aturan-aturan keputusan, dapat dengan mudah dikebangkan atau diperluas untuk permasalahan yang melbatkan sampelberukuran kecil. Satu-satunya perbedaan yang ada adalah skor z, atau statistik z digantikan dengan skor $\mathrm{t}$, atau statistik t yang bersesuaian. 
Untuk menguji $\mathrm{H}_{0}$ bahwa suatu populasi normal memiliki mean, $\mu$ dengan menggunakan:

$$
T=\frac{X-\mu}{S} \sqrt{N-1}=\frac{X-\mu}{\hat{s}} \sqrt{N}
$$

Dimana $\mathrm{x}$ adalah mean dari suatu sampel berukuran N. Ini beranalogi dengan penggunaan skor $\mathrm{z}$

$$
z=\frac{X-\mu}{\sigma / \sqrt{N}}
$$

Untuk ukuran sampel $\mathrm{N}$ yang besar, dengan pengecualian bahwa

$$
\hat{s}=\sqrt{n /(N-1)} s
$$

digunakan sebagai $\sigma$. Perbedaan adalah bahwa $\mathrm{z}$ terdistribusi normal, sedangkan t mengikuti distribusi Student. Dengan semakin meningkatnya $\mathrm{N}$, keduanya akan cenderung memperoleh hasil yang sama.

\section{Selisih Mean}

Sampel acak yang masing-masing berukuran $\mathrm{N}_{1}$ dan $\mathrm{N}_{2}$ diambil dari populasi-populasi normal yang memiliki deviasi standar sama $\left(\sigma_{1}=\sigma_{2}\right)$. Untuk menguji hipotesis $\mathrm{H}_{0}$ bahwa kedua sampel berasal dari populasi yang sama $\left(\mu_{1}=\mu_{2}\right.$ dan $\left.\sigma_{1}=\sigma_{2}\right)$, maka dapat digunakan skor $\mathrm{t}$ yang dirumuskan dengan persamaan :

Dimana

$$
t=\frac{X_{1}-X_{2}}{\sigma \sqrt{\frac{1}{N_{1}}+\frac{1}{N_{2}}}}
$$

$$
\sigma=\sqrt{\frac{N_{1} s_{1}^{2}+N_{2} s_{2}^{2}}{N_{1}+N_{2}-2}}
$$

Distribusi t menikuti distribusi student dengan $v=N_{1}+N_{2}-2$ derajat kebebasan. Dan secara keharusan hipotesa yang akan diajukan sebagai berikut :

a. $\mathrm{H}_{1}$ : Travel timePublik transport $\left(\mathrm{X}_{1 \mathrm{a}}\right)$ terdistibusi normal

$\mathrm{H}_{0} \quad$ : Travel time Publik Transport $\left(\mathrm{X}_{1 \mathrm{a}}\right)$ distribusi tidak normal

$\mathrm{H}_{1} \quad$ : Travel time Non Publik transport $\left(\mathrm{X}_{1 \mathrm{~b}}\right)$ terdistribusi normal 
$\mathrm{H}_{0} \quad$ : Travel time Non Publik transport $\left(\mathrm{X}_{1 \mathrm{~b}}\right)$ terdistibusi tidak normal

b. $\mathrm{H}_{1}$ : Data kemacetan Mariana $\left(\mathrm{X}_{2 \mathrm{a}}\right)$ Normal

$\mathrm{H}_{0} \quad$ : Data kemacetan Mariana $\left(\mathrm{X}_{2 \mathrm{a}}\right)$ Tidak Normal

$\mathrm{H}_{1} \quad$ : Data waktu tunggu Kedatangan angkot( $\left.\mathrm{X}_{2 \mathrm{~b}}\right)$ Normal

$\mathrm{H}_{0} \quad$ : Data waktu tunggu kedatangan angkot $\left(\mathrm{X}_{2 \mathrm{~b}}\right)$ Tidak Normal

c. $\mathrm{H}_{1}$ : Data kemacetan Plaju(X $\left.\mathrm{X}_{3 \mathrm{a}}\right)$ Normal

$\mathrm{H}_{0} \quad$ : Data kemacetan Plaju $\left(\mathrm{X}_{\mathrm{a}}\right)$ Tidak Normal

$\mathrm{H}_{1} \quad$ : Data waktu naik angkot $\left(\mathrm{X}_{3 \mathrm{~b}}\right)$ Normal

$\mathrm{H}_{0} \quad$ : Data waktu naik angkot $\left(\mathrm{X}_{3 \mathrm{~b}}\right)$ Tidak Normal

d. $\mathrm{H}_{1}$ : Data kemacetan Giant mall $\left(\mathrm{X}_{4 \mathrm{a}}\right)$ Normal

$\mathrm{H}_{0} \quad$ : Data kemacetan Giant mall $\left(\mathrm{X}_{4 \mathrm{a}}\right)$ Tidak Normal

$\mathrm{H}_{1} \quad$ : Data waktu turun angkot $\left(\mathrm{X}_{4 \mathrm{~b}}\right)$ Normal

$\mathrm{H}_{0} \quad$ : Data waktu turun angkot $\left(\mathrm{X}_{4 \mathrm{~b}}\right)$ Tidak Normal

e. $\mathrm{H}_{1}$ : Data kemacetan $\operatorname{Nagaswidak}\left(\mathrm{X}_{4 \mathrm{a}}\right)$ Normal

$\mathrm{H}_{0} \quad$ : Data kemacetan Nagaswidak $\left(\mathrm{X}_{4 \mathrm{a}}\right)$ Tidak Normal

$\mathrm{H}_{1} \quad$ : Data waktu berangkat angkot $\left(\mathrm{X}_{4 \mathrm{~b}}\right)$ Normal

$\mathrm{H}_{0} \quad$ : Data waktu berangkat angkot $\left(\mathrm{X}_{4 \mathrm{~b}}\right)$ Tidak Normal

Untuk X6 hingga X 12, data merupakan data populasi yang tidak perlu diadakan pengujian

Hal ini dikarenakan data sudah standar menurut aturan kecepatan dan ship simulator

I. Kelompok Faktor Karakteristik Sistem transportsi (Transportation System Characteristic Factor)

Pada faktor ini, seluruh variabel yang berpengaruh terhadap perilaku si pembuat perjalanan dalam memilih moda transportasi berhubungan dengan kinerja pelayanan system transportasi seperti berikut :

1. Variabel waktu relative (lama) perjalanan (relative travel time) mulai dari lamanya waktu menunggu kendaraan di pemberhentian (terminal), waktu jalan ke terminal (walk to terminal time) dan waktu di atas kendaraan.

Variabel waktu perjalanan ini dapat diperbandingkan untuk dipilih di antara waktu-waktu perjalanan moda-moda transportasi yang tersedia, sehingga timbul suatu kompetisi sehat antara moda yang satu dengan moda lain untuk saling menawarkan pelayanan terbaik (waktu yang tersingkat) kepada calon pelaku perjalanan. Untuk perbandingan waktu perjalanan antara 2 moda yang saling 
berkompetisi ini, Nasional Capital Transportation Agency (NCTA) telah mengembangkan sebuah model yang disebut dengan Rasio Waktu Perjalanan (RWP) / Travel Time Ratio (TTR). Model ini, oleh NCTA hanya membandingkan gambaran waktu perjalanan antara moada transportasi umum (Public Transport) dengan moda transportai penyeberangan (Ferrys transport). Adapun bentuk tipikal model dimaksud adalah (Bruton, M.J, 1985)

$R W P\left(\right.$ Rasio Waktu Perjalanan $=\frac{X_{1}+X_{2}+X_{3}+X_{4}+X_{5}}{X_{6}+X_{7}+X_{8}}$

Dimana :

$\mathrm{X}_{1}=$ Waktu berkendaraan angkutan umum.

$\mathrm{X}_{2}=$ Waktu ganti moda antara angkutan umum 1 dengan angkutan umum 2 (misalnya antara mikrolet dengan bus umum).

$\mathrm{X}_{3}=$ Waktu menunggu angkutan umum.

$\mathrm{X}_{4}=$ Waktu berjalan ke pemberhentian angkutan umum di tempat asal.

$\mathrm{X}_{5}=$ Waktu berjalan dari angkutan umum di tempat tujuan.

$\mathrm{X}_{6}=$ Waktu tempuh perjalanan penyeberangan

$\mathrm{X}_{7}=$ Waktu menunggu keberangkatan di Pel penyeberangan.

$\mathrm{X}_{8}=$ Waktu berjalan dari kapal keluar dan transit.

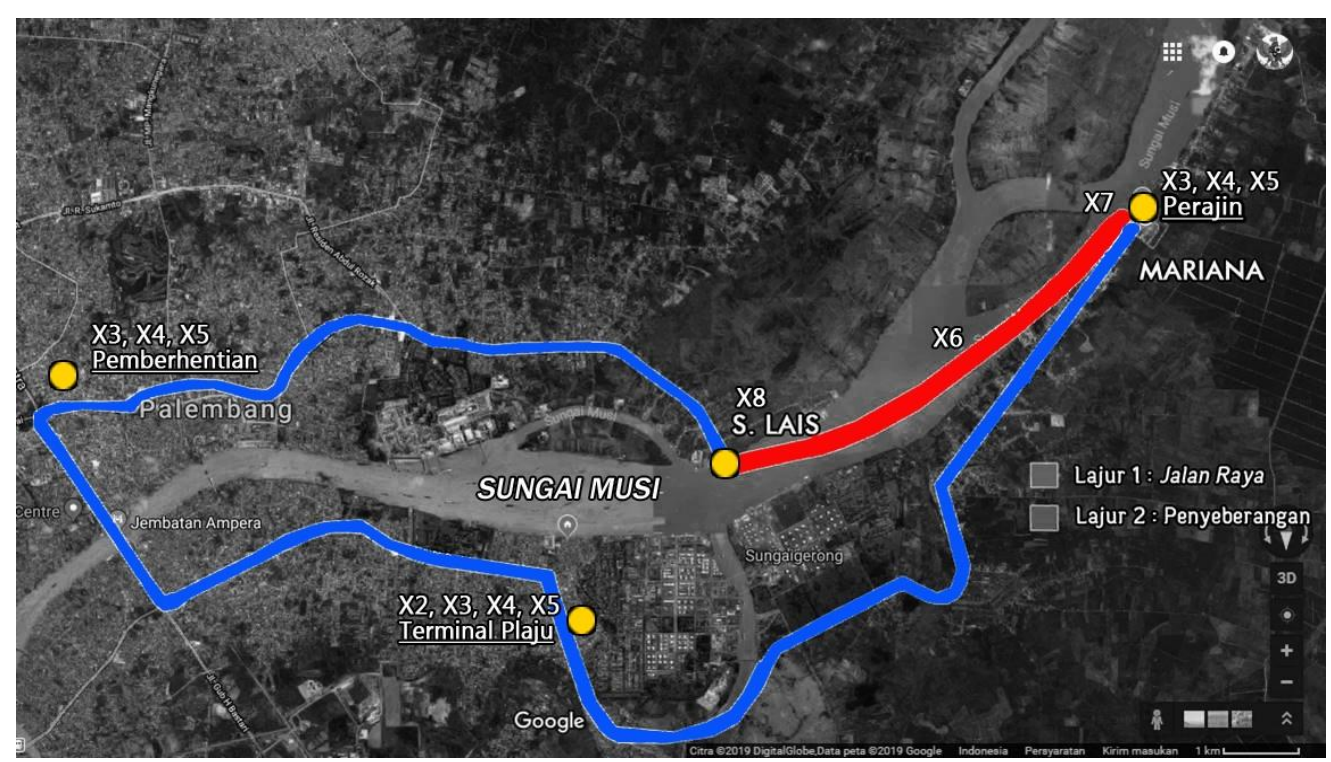

Adapun RWP untuk kendaraan pribadi di jelaskankan pada Gambar berikut ini: 


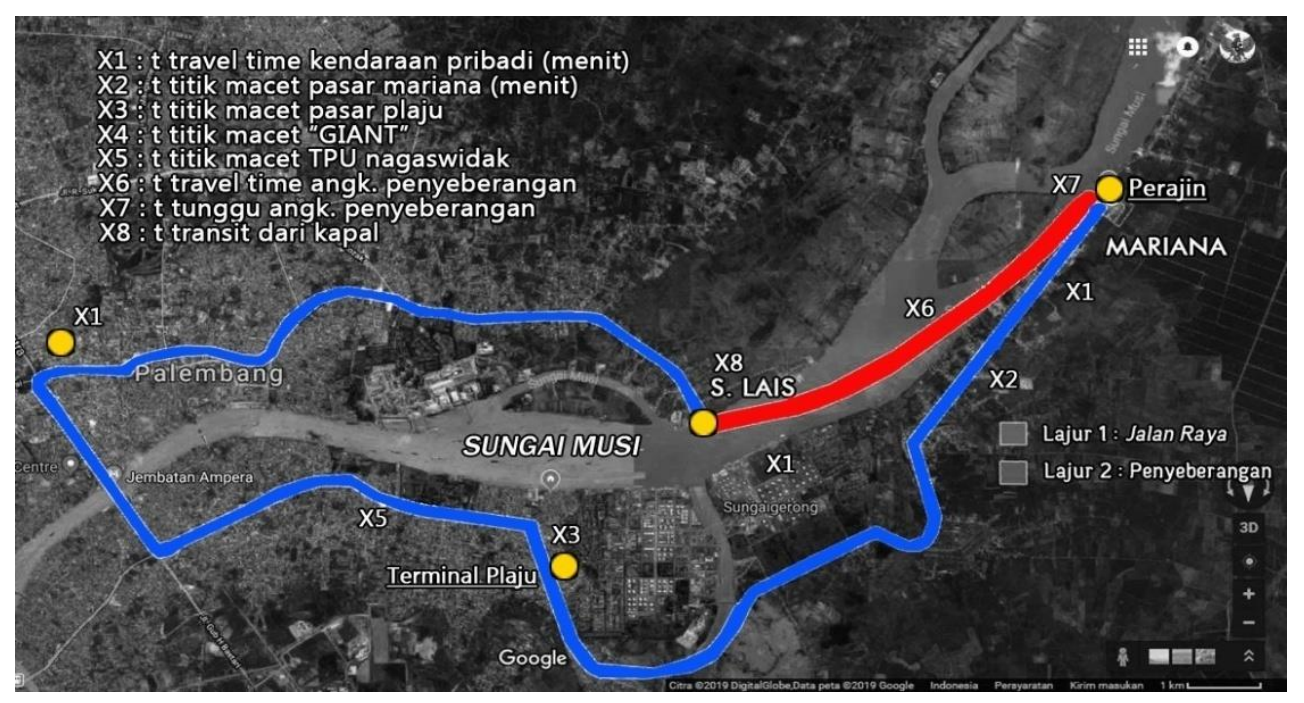

2. Variabel Biaya Relatif Perjalanan (Relative Travel Cost), merupakan seluruh biaya yang timbul akibat melakukan perjalanan dari asal ke tujuan untuk semua moda yang berkompetisi seperti tarif tiket, bahan bakar dan lain-lain.

Kembali NCTA juga memodelkan perbandingan antara biaya yang timbul akibat memakai moda-moda angkutan yang tersedia. Seperti halnya variabel waktu di atas, biaya inipun dibandingkan antar biaya angkutan umum dengan biaya angkutan pribadi yang disebut dengan Rasio Biaya Perjalanan (RBP) / Travel Cost Ratio (TCR). Bentuk model RBP adalah :

$$
R B P(\text { Rasio Biaya Perjalanan })=\frac{X_{9}+X 10}{X 11+X 12}
$$

Dimana :

$\mathrm{X}_{9}=$ Biaya Angkutan Umum Prajen pelaju

$\mathrm{X}_{10} \quad=$ Biaya angkot Plaju- Plg ilir

$\mathrm{X}_{11} \quad=$ Biaya angkutan penyebrangan i Prajen-Plg ilir

$\mathrm{X}_{12} \quad=$ Biaya dari rumah ke Pelabuhan.

Variabel nomor 1 dan variable nomor 2 merupakan kelompok variable dapat diukur (dikuantifikasikan).

$\mathrm{X}_{9}=$ Biaya Kendaraan pribadi Prajen pelaju

$\mathrm{X}_{10} \quad=$ Biaya Kend Pribadi Plaju- Plg ilir

$\mathrm{X}_{11} \quad=$ Biaya angkutan penyeberangan Prajen-Plg ilir

$\mathrm{X}_{12}=$ Biaya dari rumah ke Pelabuhan Penyeberangn.

2. Variabel Tingkat Pelayanan Relatif (Rlatif Level Of Service)

3. Variabel tingkat akses/indeks daya hubung/kemudahan pencapaian tempat tujuan

4. Variabel tingkat kehandalan angkutan umum di segi waktu (tepat waktu/reliability), ketersediaan ruang parker dan tarif. 
Ketiga variable yang terakhir ini (3, 4, dan 5) merupakan kelompok variable yang sangat subjektif sehingga sulit diukur (dikuantifikasikan) dan masuk kelompok variable kualitatif (difficult to quantify). Namun NCTA mencoba merasiokan tingkat pelayanan relative melalui model berikut :

$$
R P P(\text { Rasio Pelayanan Perjalanan })=\frac{X_{2}+X_{3}+X_{4}+X_{5}}{X_{7}+X_{8}}
$$

\section{HASIL DAN PEMBAHASAN.}

Pembahasan ini meliputi, kegiatan analisis data berdasarkan uji hipotesa, dari data yang diambil dari survai mulai dari data perjalanan, kemacetan, waktu pelayanan, waktu tunggu atau secara variable yaitu dimulai dari variable $\mathrm{X}_{1}$ hingga variable $\mathrm{X}_{5}$, tapi utk variable $\mathrm{X} 6$ hingga X12 tidak dilakukan uji statistic karena datanya diolah berdasarkan ketentuan peraturan Mentri dan data simulasi

\section{Hipotesa Travel Time Public Transport}

Tabel 4.I

Data Travel Time Public Transport(menit)

\begin{tabular}{|c|c|c|}
\hline NO & OBJEK & PENGUKURAN $\left(\mathrm{X}_{1}\right)$ \\
\hline 1 & Angkot & 51 \\
\hline 2 & Angkot & 65 \\
\hline 3 & Bis & 68 \\
\hline 4 & Bis & 56 \\
\hline 5 & Bis & 57 \\
\hline 6 & Angkot & 50 \\
\hline 7 & Bis & 52 \\
\hline 8 & Bis & 56 \\
\hline 9 & Bis & 56 \\
\hline 10 & Bis & 60 \\
\hline 11 & Angkot & 51 \\
\hline 12 & Angkot & 51 \\
\hline 13 & Angkot & 63 \\
\hline 14 & Angkot & 67 \\
\hline 15 & Bis & 68 \\
\hline 16 & Angkot & 68 \\
\hline 17 & Angkot & 68 \\
\hline 18 & Angkot & 62 \\
\hline 19 & Angkot & 62 \\
\hline 20 & Angkot & 62 \\
\hline \multicolumn{2}{|r|}{ TOTAL } & 1193 \\
\hline \multicolumn{2}{|c|}{ Rata-rata } & 58,80 \\
\hline \multicolumn{2}{|c|}{ Standar Deviasi Sampel } & 1 \\
\hline \multicolumn{2}{|c|}{ Standar Deviasi Populasi } & 1 \\
\hline
\end{tabular}


Lebar Gang Way

Diketahui :
$\mathrm{n} \quad=20$
$\mu \quad=62$
$\sigma \quad=2,99$
$\alpha \quad=5 \%$
$\chi \quad=58,88$

a. Formula Hipotesis

$\mathrm{H}_{0}: \mu=62$ Menit

$\mathrm{H}_{\mathrm{a}}: \mu<62$ Menit

b. Taraf Nyata dan Nilai t Tabel

$\alpha=5 \% ; \alpha / 2=2,5 \% ; \mathrm{db} \quad=20-1=19$

$\mathrm{t}_{2.5 \% ; 24}=2,093$

c. Kriteria Pengujian

$\mathrm{H}_{0}$ diterima jika $=-2,093 \leq \mathrm{t}_{0} \quad \geq 2,093$

$\mathrm{H}_{0}$ ditolak jika $=\mathrm{t}_{0}>2,093$ atau $\mathrm{t}_{0}<-2,093$

d. Uji Statistik

a. $t_{0}=\frac{\chi-\mu_{0}}{\frac{\sigma}{\sqrt{n}}}$

$$
\begin{aligned}
& t_{0}=\frac{58,80-1}{\frac{1}{\sqrt{20}}} \\
& t_{0}=-14,891
\end{aligned}
$$

b. $\chi-t_{\frac{\alpha}{2}} \cdot \frac{\sigma}{\sqrt{n}} \leq \mu \leq \chi+t_{\frac{\alpha}{2}} \cdot \frac{\sigma}{\sqrt{n}}$

$58,88-t_{\frac{0.5}{2}} \cdot \frac{1}{\sqrt{20}} \leq \mu \leq 58,88+t_{\frac{0.5}{2}} \cdot \frac{1}{\sqrt{20}}$

$58,80-2,093 \cdot \frac{1}{\sqrt{20}} \leq \mu \leq 58,80+2,093 \cdot \frac{1}{\sqrt{20}}$

$54,67 \leq \mu \leq 63,38$

e. Kesimpulan

Jadi uji hipotesis menyimpulkan bahwa $\mathrm{H}_{0}$ ditolak

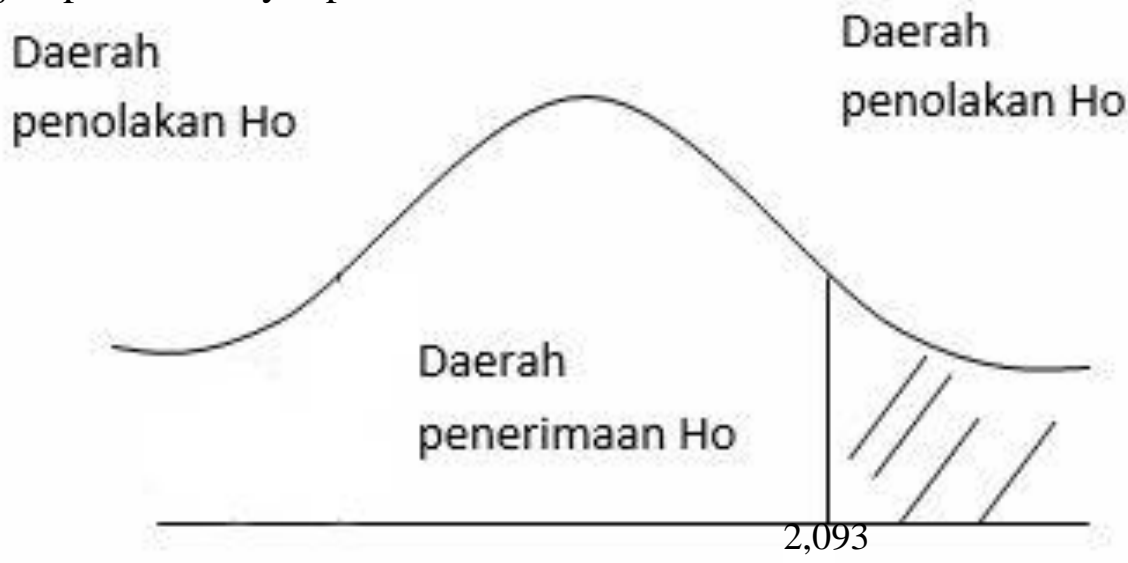


Tabel 4.2

Hasil Uji Hipotesa

\begin{tabular}{|c|c|c|c|c|c|}
\hline $\begin{array}{l}\mathrm{N} \\
\mathrm{O}\end{array}$ & $\begin{array}{l}\text { VA } \\
\text { R }\end{array}$ & OBJEK UJI & HASIL TEST & KET. & $\begin{array}{c}\text { KESIMPUL } \\
\text { AN }\end{array}$ \\
\hline 1 & $\mathbf{X}_{1 \mathbf{a}}$ & travel time angkot & $t_{0}=\frac{\chi-\mu_{0}}{\frac{\sigma}{\sqrt{n}}}$ & $-5,91<-2,903$ & $\mathrm{H}_{0}=$ ditolak \\
\hline 2 & $\mathbf{X}_{1 b}$ & travel time non angkot & $t_{0}=\frac{\chi-\mu_{0}}{\frac{\sigma}{\sqrt{n}}}$ & $\mathbf{- 1 4 , 2}<-2,97$ & $\mathrm{H}_{0}=$ ditolak \\
\hline 3 & $\mathbf{X}_{2 \mathbf{a}}$ & kemacetan mariana & $t_{0}=\frac{\chi-\mu_{0}}{\frac{\sigma}{\sqrt{n}}}$ & $-3,12<2,784$ & $H_{0}=$ ditolak \\
\hline 4 & $\mathbf{X}_{2 b}$ & waktu tunggu angkot & $t_{0}=\frac{\chi-\mu_{0}}{\frac{\sigma}{\sqrt{n}}}$ & $-13,98<2,093$ & $\mathrm{H}_{0}=$ ditolak \\
\hline 5 & $\mathbf{X}_{\mathbf{3 a}}$ & kemacetan plaju & $t_{0}=\frac{\chi-\mu_{0}}{\frac{\sigma}{\sqrt{n}}}$ & $-13,98<2,093$ & $\mathbf{H}_{0}=$ ditolak \\
\hline 6 & $\mathbf{X}_{3 \mathbf{b}}$ & waktu naik angkot & $t_{0}=\frac{\chi-\mu_{0}}{\frac{\sigma}{\sqrt{n}}}$ & $-13,98<2,093$ & $H_{0}=$ ditolak \\
\hline & $\mathbf{X}_{4 \mathbf{a}}$ & kemacetan giant & $t_{0}=\frac{\chi-\mu_{0}}{\frac{\sigma}{\sqrt{n}}}$ & $-13,98<2,093$ & $\mathrm{H}_{0}=$ ditolak \\
\hline 8 & $\mathbf{X}_{\mathbf{4 b}}$ & waktu turun angkot & $t_{0}=\frac{\chi-\mu_{0}}{\frac{\sigma}{\sqrt{n}}}$ & $-13,98<2,093$ & $\mathrm{H}_{0}=$ ditolak \\
\hline 9 & $\mathbf{X}_{5 \mathbf{a}}$ & kemacetan nagaswidak & $t_{0}=\frac{\chi-\mu_{0}}{\frac{\sigma}{\sqrt{n}}}$ & $-13,98<2,093$ & $\mathrm{H}_{0}=$ ditolak \\
\hline & $\mathbf{X}_{5 b}$ & $\begin{array}{l}\text { waktu tunggu } \\
\text { berangkat }\end{array}$ & $t_{0}=\frac{\chi-\mu_{0}}{\frac{\sigma}{\sqrt{n}}}$ & $-13,98<2,093$ & $\mathbf{H}_{0}=$ ditolak \\
\hline
\end{tabular}

Indikasi menunjukkan bahwa bila $\mathbf{H}_{\mathbf{0}}=$ ditolak, maka data dapat dinyatakan terdistribusi Normal, ini berarti data cukup valid untuk digunakan sebagai bahan analisis 


\section{RASIO WAKTU PERJALANAN NON PUBLIK TRANSPORT DENGAN PENYEBERANGAN.}

Rasio waktu perjalanan yang digunakan sebagai analisis ini di adopsi dari persamaan (4.36) dimana waktu perjalanan Non Publik transport (TTPr/Travel Time Kendaraan Pribadi) atau dikenal dengan Private Car di reprentasikan oleh X1 sampai dengan X5 sedangkan waktu perjalanan penyeberangan ( TTPy/ Travel Time penyeberangan).di presentasikan oleh variable $\mathrm{X}_{6}, \mathrm{X}_{7}$ dan $\mathrm{X}_{8}$. Hasil yang didapat bahwa perbandingan TTPr dengan TTPy bahwa waktu perjalanan dengan menggunakan jalan raya/angkot adalah 307 persen lebih lama jika dibandingkan dengan dengan menggunakan angkutan penyeberangan melalui sungai atau waktu tempuh Non public transport atau private car adalah tiga kali lebih lama dari

Peneberangan ,dengan kata lain bahwa menggunakan ankutan penyeberangan atau lebih dikenal dengan ferry transport lebih singkat waktu perjalanan dari Prajen- Palembang ilir P dengan rasio waktu per jalanan 3,07 kali. Secara ekonomis waktu yang lebih singkat akan memberikan dampak yang positif bagi para pelaku perjalanan utamanya pelakuk perjalanan yang menggunakan angkutan pribadi, karena para pelaku perjalanan biasanya sifat perjalanan yang dilakukan merupakan kegiatan yang bersifat rutinitas seperti untuk bekerja , perdagangan, sekolah dan urusan urusan yang mendukung pertumbuhan ekonomi suatu wilayah Untuk lebih rinci dapat dilihat pada tabel berikut ini :

\section{Tabel 4.3}

Rasio Waktu Perjalanan (RWP) Non Publik Transport

Dengan Penyeberangan (Menit)

\begin{tabular}{|c|c|c|c|}
\hline NO & $\boldsymbol{\Sigma}$ TTPr & $\boldsymbol{\Sigma}$ TTPy & RWP \\
\hline $\mathbf{1}$ & 65 & 23 & 2,83 \\
\hline $\mathbf{2}$ & 75 & 24 & 3,13 \\
\hline $\mathbf{3}$ & 78 & 25 & 3,12 \\
\hline $\mathbf{4}$ & 70 & 24 & 2,92 \\
\hline $\mathbf{5}$ & 70 & 24 & 2,92 \\
\hline $\mathbf{6}$ & 72 & 25 & 2,88 \\
\hline $\mathbf{7}$ & 75 & 25 & 3,00 \\
\hline $\mathbf{8}$ & 65 & 26 & 2,60 \\
\hline $\mathbf{9}$ & 70 & 25 & 2,69 \\
\hline $\mathbf{1 0}$ & 71 & 24 & 2,84 \\
\hline $\mathbf{1 1}$ & 73 & 24 & 3,04 \\
\hline $\mathbf{1 2}$ & 74 & 24 & 3,08 \\
\hline $\mathbf{1 3}$ & 77 & 24 & 3,20 \\
\hline $\mathbf{1 4}$ & 78 & 26 & 3,00 \\
\hline
\end{tabular}




\begin{tabular}{|c|c|c|c|}
\hline $\mathbf{1 5}$ & 72 & 26 & 2,69 \\
\hline $\mathbf{1 6}$ & 72 & 27 & 2,77 \\
\hline $\mathbf{1 7}$ & 69 & 24 & 2,55 \\
\hline $\mathbf{1 8}$ & 64 & 24 & 2,67 \\
\hline $\mathbf{1 9}$ & 66 & 23 & 2,75 \\
\hline $\mathbf{2 0}$ & 72 & 26 & 3,13 \\
\hline RWP & $\mathbf{7 4 , 2 1}$ & $\mathbf{2 4 , 1 5}$ & $\mathbf{3 , 0 7}$ \\
\hline
\end{tabular}

Catatan

TTPr $\quad=$ Travel Time Kend Pribadi

TTPy $=$ Travel Time Penyeberangan

RWP $\quad=$ Rasio Waktu Perjalanan

Secara kuantitatif nilai rasio waktu perjalan ini, sangat menggambarakan kinerja kedua moda transport ini, yaitu moda angkut jalan raya dan moda angkut penyeberangan, ini dapat dilihat pada sampel yang pertama rasio bisa mencapai 2,83 atau 283 persen, untuk sampel yang diambil pada kegiatan yang kesepuluh rasio tidak jauh berbeda yaitu 2,84 atau 284 persen. Nilai rasio yang terendah 2,55 atau 255 persen dan nilai rasio yang tertinggi adalah 3,20 atau 320 persen, ini berarti secara keseluruhan memang angkutan penyeberangan pada lintas kajian lebih efektif dan menguntungkan bagi para pengguna jasa angkutan. Pada tabel IV.12 adalah hasil analisis rasio waktu perjalanan untuk angkutan umum/public transport, dimana hasil dari perbandingan sampel pertama yang diambil adalah bernilai 2,83 atau 283 persen yang berarti efektifitas perjalanan yang digunakan untuk moda angkut penyeberangan lebih cepat 2,83 kali dari bila menggunakan angkutan jalan, hal ini di mungkinkan karena factor jarak yang relative lebih pendek dan factor hambatan pelayanan yang diperkirakan lebih sederhana. Untuk nilai rata rata seluruh data didapatkan nilai rasio waktu perjalanan sekitar 3,25 kali atau 325 persen dari 20 data yang disandingkan hal ini menunjukkan bahwa secara signifikan angkutan penyeberangan memang layak di operasikan secara teknis.

Tabel 4.4

Rasio Waktu Perjalanan (RWP) Publik Transport

Dengan Penyeberangan(Menit)

\begin{tabular}{|c|c|c|c|}
\hline NO & $\boldsymbol{\Sigma}$ TTPr & $\boldsymbol{\Sigma}$ TTPy & RWP \\
\hline $\mathbf{1}$ & 73 & 23 & 2,83 \\
\hline $\mathbf{2}$ & 81 & 24 & 3,13 \\
\hline $\mathbf{3}$ & 89 & 25 & 3,12 \\
\hline $\mathbf{4}$ & 76 & 24 & 2,92 \\
\hline $\mathbf{5}$ & 74 & 24 & 2,92 \\
\hline $\mathbf{6}$ & 69 & 25 & 2,88 \\
\hline $\mathbf{7}$ & 74 & 25 & 3,00 \\
\hline
\end{tabular}




\begin{tabular}{|c|c|c|c|}
\hline $\mathbf{8}$ & 81 & 25 & 2,60 \\
\hline $\mathbf{9}$ & 72 & 26 & 2,69 \\
\hline $\mathbf{1 0}$ & 76 & 25 & 2,84 \\
\hline $\mathbf{1 1}$ & 70 & 24 & 3,04 \\
\hline $\mathbf{1 2}$ & 67 & 24 & 3,08 \\
\hline $\mathbf{1 3}$ & 79 & 24 & 3,20 \\
\hline $\mathbf{1 4}$ & 87 & 26 & 3,00 \\
\hline $\mathbf{1 5}$ & 89 & 26 & 2,69 \\
\hline $\mathbf{1 6}$ & 90 & 27 & 2,77 \\
\hline $\mathbf{1 7}$ & 85 & 24 & 2,55 \\
\hline $\mathbf{1 8}$ & 77 & 24 & 2,67 \\
\hline $\mathbf{1 9}$ & 67 & 23 & 2,75 \\
\hline $\mathbf{2 0}$ & 68 & 26 & 3,13 \\
\hline RWP & $\mathbf{7 8 , 5}$ & $\mathbf{2 4 , 1 5}$ & $\mathbf{3 , 2 5}$ \\
\hline
\end{tabular}

Catatan

TTPr = Travel Time Publik Transport/Angkot

TTPy = Travel Time Penyeberangan

RWP = Rasio Waktu Perjalanan

\section{RASIO BIAYA PERJALANAN (RBP)}

Rasio biaya perjalanan ini, dikaji atas dua aspek yaitu dari sisi biaya perjalanan angkutan penyeberangan dengan angkutan public transport dan non public transport, Hal ini dibedakan karena karakter dari publik transport sangat berbeda dengan non publik transport terutama karakter pola perjalanan dan kondisi pelayanannya.

Pada tabel IV.13 rasio biaya perjalanan untuk public transport yang disandingkan dengan moda angkut penyeberangan mempunyai nilai 1,33 hingga 1,57 atau rata rata nilai rasio biayanya adalah 1,38 atau bernilai 138 ;persen, walaupun secara kuantitatif nilai nya tidak terlalu jauh ber beda tapi yang jelas RBP> 1 atau dapat dikatakan angkutan penyeberangan atau ferry lebih hemat bila ditinjau dari biaya operasional.

Tabel 4.5

Rasio Biaya Perjalanan Angkot VS Penyeberangan

\begin{tabular}{|c|c|c|c|}
\hline NO & $\boldsymbol{\Sigma}$ Ctr $_{\mathbf{A}}$ & $\boldsymbol{\Sigma}$ Ctrp & Rasio \\
\hline $\mathbf{1}$ & 10.000 & 7.000 & 1,43 \\
\hline $\mathbf{2}$ & 10.000 & 7.000 & 1,43 \\
\hline $\mathbf{3}$ & 10.000 & 7.000 & 1,43 \\
\hline $\mathbf{4}$ & 10.000 & 7.000 & 1,43 \\
\hline $\mathbf{5}$ & 16.000 & 12.000 & 1,33 \\
\hline $\mathbf{6}$ & 16.000 & 12.000 & 1,33 \\
\hline $\mathbf{7}$ & 16.000 & 12.000 & 1,33 \\
\hline
\end{tabular}




\begin{tabular}{|c|c|c|c|}
\hline 8 & 16.000 & 12.000 & 1,33 \\
\hline 9 & 16.000 & 12.000 & 1,33 \\
\hline 10 & 16.000 & 12.000 & 1,33 \\
\hline 11 & 16.000 & 12.000 & 1,33 \\
\hline 12 & 16.000 & 12.000 & 1,33 \\
\hline 13 & 16.000 & 12.000 & 1,33 \\
\hline 14 & 11.000 & 7.000 & 1,57 \\
\hline 15 & 11.000 & 7.000 & 1,57 \\
\hline 16 & 11.000 & 7.000 & 1,57 \\
\hline 17 & 11.000 & 7.000 & 1,57 \\
\hline 18 & 11.000 & 7.000 & 1,57 \\
\hline 19 & 17.000 & 12.000 & 1,41 \\
\hline 20 & 17.000 & 12.000 & 1,41 \\
\hline Jumlah & 261.000 & 195.000 & 26,77 \\
\hline $\begin{array}{c}\text { Rata- } \\
\text { rata }\end{array}$ & 13.050 & 9.750 & 1,38 \\
\hline
\end{tabular}

Keterangan :

$\mathrm{Ctr}_{\mathrm{A}}=$ Cost Transport Angkot

$\mathrm{Ctr}_{\mathrm{P}}=$ Cost Transport Ferry

Pada tabel, adalah hasil analisa data dari private cars dengan angkutan penyeberangan yang ditinjau dari rasio biaya perjalanan ,nilai yang didapat dari hasil analisis bahwa pada sampel pertama RBP nya mencapai nilai 1,25 atau 125 persen dengan istilah ekonomi dikatakan biaya operasi untuk angkutan non public transport lebih mahal sekitar 25 persen per moda bila menggunakan lintas angkutan jalan., secara rata rata juga menghasilkan nilai yang sama persis pada setiap sampel, untuk jelasnya dapat dilihat pada tabel IV.14 berikut ini

Tabel 4.6

RBP Non Publik Transport VS Penyeberangan

\begin{tabular}{|c|c|c|c|}
\hline NO & $\boldsymbol{\Sigma}$ CTRPR & $\boldsymbol{\Sigma}$ CTRpy & Rasio \\
\hline $\mathbf{1}$ & 15.000 & 12.500 & 1,25 \\
\hline $\mathbf{2}$ & 15.000 & 12.500 & 1,25 \\
\hline $\mathbf{3}$ & 15.000 & 12.500 & 1,25 \\
\hline $\mathbf{4}$ & 15.000 & 12.500 & 1,25 \\
\hline $\mathbf{5}$ & 15.000 & 12.500 & 1,25 \\
\hline $\mathbf{6}$ & 15.000 & 12.500 & 1,25 \\
\hline $\mathbf{7}$ & 15.000 & 12.500 & 1,25 \\
\hline $\mathbf{8}$ & 15.000 & 12.500 & 1,25 \\
\hline $\mathbf{9}$ & 15.000 & 12.500 & 1,25 \\
\hline $\mathbf{1 0}$ & 15.000 & 12.500 & 1,25 \\
\hline $\mathbf{1 1}$ & 15.000 & 12.500 & 1,25 \\
\hline
\end{tabular}




\begin{tabular}{|c|c|c|c|}
\hline $\mathbf{1 2}$ & 15.000 & 12.500 & 1,25 \\
\hline $\mathbf{1 3}$ & 15.000 & 12.500 & 1,25 \\
\hline $\mathbf{1 4}$ & 15.000 & 12.500 & 1,25 \\
\hline $\mathbf{1 5}$ & 15.000 & 12.500 & 1,25 \\
\hline $\mathbf{1 6}$ & 15.000 & 12.500 & 1,25 \\
\hline $\mathbf{1 7}$ & 15.000 & 12.500 & 1,25 \\
\hline $\mathbf{1 8}$ & 15.000 & 12.500 & 1,25 \\
\hline $\mathbf{1 9}$ & 15.000 & 12.500 & 1,25 \\
\hline $\mathbf{2 0}$ & 15.000 & 12.500 & 1,25 \\
\hline Jumlah & $\mathbf{3 0 0 . 0 0 0}$ & $\mathbf{2 5 0 . 0 0 0}$ & $\mathbf{2 5}$ \\
\hline $\begin{array}{c}\text { Rata- } \\
\text { rata }\end{array}$ & $\mathbf{1 5 . 0 0 0}$ & $\mathbf{1 2 . 5 0 0}$ & $\mathbf{1 , 2 5}$ \\
\hline
\end{tabular}

\section{Keterangan:}

$\mathrm{CTR}_{\mathrm{PR}}$ : Biaya Perjalanan Non public transport/Private cars

CTRpy: Biaya perjalanan Penyeberangan

\section{RASIO PELAYANAN PERJALANAN.}

Rasio pelayanan perjalanan ini, dikaji atas dua aspek yaitu dari sisi biaya perjalanan angkutan penyeberangan dengan angkutan public transport dan non public transport, Hal ini dibedakan karena karakter dari publik transport sangat berbeda dengan non publik transport terutama karakter pola perjalanan dan kondisi pelayanannya.Pada tabel IV.15 rasio pelayanan perjalanan untuk public transport yang disandingkan dengan moda angkut penyeberangan mempunyai nilai 0,93 hingga 1,09 atau rata rata nilai rasio pelayanan nya adalah 1,06 atau bernilai 106 ;persen, walaupun secara kuantitatif nilai nya tidak terlalu jauh ber beda tapi yang jelas $\mathrm{RBP}>1$ atau dapat dikatakan angkutan penyeberangan atau ferry lebih baik sedikit walaupun sedikit sekali bila ditinjau dari pelayanan operasional.

Tabel 4.7

Ratio Pelayanan Perjalanan Angkot-Ferry

\begin{tabular}{|c|c|c|c|}
\hline NO & $\begin{array}{c}\boldsymbol{\Sigma} \\
\text { PPA(menit) }\end{array}$ & $\mathbf{\Sigma P P F ( m e n i t )}$ & Rasio \\
\hline $\mathbf{1}$ & 10 & 10,81 & 0,925 \\
\hline $\mathbf{2}$ & 9 & 10,78 & 0,83 \\
\hline $\mathbf{3}$ & 12 & 10,8 & 1,11 \\
\hline $\mathbf{4}$ & 14 & 11,1 & 1,26 \\
\hline $\mathbf{5}$ & 10 & 11,2 & 0,89 \\
\hline $\mathbf{6}$ & 10 & 11,35 & 0,88 \\
\hline $\mathbf{7}$ & 8 & 11,47 & 0,70 \\
\hline $\mathbf{8}$ & 11 & 12,3 & 0,88 \\
\hline
\end{tabular}




\begin{tabular}{|c|c|c|c|}
\hline $\mathbf{9}$ & 14 & 11,8 & 1,19 \\
\hline $\mathbf{1 0}$ & 13 & 12,6 & 1,03 \\
\hline $\mathbf{1 1}$ & 13 & 12,6 & 1,03 \\
\hline $\mathbf{1 2}$ & 9 & 12,6 & 0,71 \\
\hline $\mathbf{1 3}$ & 11 & 11,1 & 0,99 \\
\hline $\mathbf{1 4}$ & 11 & 10,8 & 1,03 \\
\hline $\mathbf{1 5}$ & 10 & 9,2 & 1,10 \\
\hline $\mathbf{1 6}$ & 8 & 10,3 & 0,80 \\
\hline $\mathbf{1 7}$ & 7 & 10,4 & 0,70 \\
\hline $\mathbf{1 8}$ & 12 & 10,4 & 1,15 \\
\hline $\mathbf{1 9}$ & 12 & 10,4 & 1,15 \\
\hline $\mathbf{2 0}$ & 9 & 11,5 & 0,80 \\
\hline $\begin{array}{c}\text { Jumlah } \\
\text { Rata- } \\
\text { rata }\end{array}$ & $\mathbf{2 3 7}$ & $\mathbf{2 2 3 , 5 1}$ & $\mathbf{2 1 , 2}$ \\
\hline & & $\mathbf{1 1 , 1 7 6}$ & $\mathbf{1 , 0 6}$ \\
\hline
\end{tabular}

Keterangan

PPA = Pelayanan Perjalanan Angkut

$\mathrm{PPB}=$ Pelayanan Perjalanan Ferry

$\mathrm{RPP}_{\mathrm{AF}}=$ Rasio Pelayanan Perjalanan Angkut-Ferry

$\mathrm{RPP}_{\mathrm{AF}}=\frac{X_{2}+X_{3}+X_{4}+X_{5}}{X_{7}+X_{8}}$

Perbandingan pelayanan perjalanan ( RPP) antara non public transport/jalan raya dengan angkutan penyeberangan yang melalui sungai seperti yang tergambar pada tabel IV.16

Bahwa jumlah waktu yang didapat oleh Private cars dalam melayani penumpang dengan 20 objek observasi adalah 230 menit menit sedangkan melaui bis air dengan sampel yang sama jumlah waktu pelayanan yang di eksplorasi adalah sekitar 188 menit dan bila dibandingkan keduanya maka angkutan jalan raya mempunyai pelayanan 1,31 kali lebih lama bila dibandingkan dengan penyeberangan atau dengan kata lain penyeberangan melalui sungai lebih effisien dari Non angkot.

Tabel 4.8

Ratio Pelayanan Perjalanan Private Car - Ferry

\begin{tabular}{|c|c|c|c|}
\hline NO & $\boldsymbol{\Sigma}$ PРКв & $\mathbf{\Sigma P P F}$ & Rasio \\
\hline $\mathbf{1}$ & 15 & 7 & 2,14 \\
\hline $\mathbf{2}$ & 14 & 8,6 & 1,63 \\
\hline $\mathbf{3}$ & 11 & 8,7 & 1,26 \\
\hline $\mathbf{4}$ & 8 & 8,7 & 0,92 \\
\hline $\mathbf{5}$ & 12 & 7,8 & 1,53 \\
\hline $\mathbf{6}$ & 7 & 8,9 & 0,78 \\
\hline $\mathbf{7}$ & 19 & 8,9 & 2,13 \\
\hline $\mathbf{8}$ & 13 & 9,0 & 1,44 \\
\hline
\end{tabular}




\begin{tabular}{|c|c|c|c|}
\hline $\mathbf{9}$ & 9 & 9,6 & 0,94 \\
\hline $\mathbf{1 0}$ & 12 & 10,2 & 1,17 \\
\hline $\mathbf{1 1}$ & 13 & 10 & 1,3 \\
\hline $\mathbf{1 2}$ & 9 & 9,5 & 0,94 \\
\hline $\mathbf{1 3}$ & 12 & 9,5 & 1,26 \\
\hline $\mathbf{1 4}$ & 13 & 8,7 & 1,49 \\
\hline $\mathbf{1 5}$ & 11 & 10,2 & 0,98 \\
\hline $\mathbf{1 6}$ & 12 & 10,9 & 1,10 \\
\hline $\mathbf{1 7}$ & 6 & 10,8 & 0,55 \\
\hline $\mathbf{1 8}$ & 13 & 9,12 & 1,42 \\
\hline $\mathbf{1 9}$ & 17 & 10,2 & 1,66 \\
\hline $\mathbf{2 0}$ & 17 & 10,2 & 1,66 \\
\hline Jumlah & $\mathbf{2 3 0}$ & $\mathbf{1 8 8}$ & $\mathbf{2 6 , 3}$ \\
\hline $\begin{array}{c}\text { Rata- } \\
\text { rata }\end{array}$ & $\mathbf{1 1 , 5}$ & $\mathbf{9 , 4}$ & $\mathbf{1 , 3 1}$ \\
\hline
\end{tabular}

\section{Keterangan :}

$\mathrm{PP}_{\mathrm{kb}} \quad=$ Pelayanan Perjalanan private cars

$\mathrm{PP}_{\mathrm{f}} \quad=$ Pelayanan Perjalanan Ferry

\subsection{KESIMPULAN}

1. Rasio waktu perjalanan yang digunakan sebagai analisis ini di adopsi dari persamaan (4.36) dimana waktu perjalanan Non Publik transport (TTPr/Travel Time Kendaraan Pribadi) atau dikenal dengan Private Car di reprentasikan oleh X1 sampai dengan X5 sedangkan waktu perjalanan penyeberangan ( TTPy/ Travel Time penyeberangan).di presentasikan oleh variable $\mathrm{X}_{6}, \mathrm{X}_{7}$ dan $\mathrm{X}_{8}$. Hasil yang didapat bahwa perbandingan TTPr dengan TTPy bahwa waktu perjalanan dengan menggunakan jalan raya/angkot adalah 307 persen lebih lama jika dibandingkan dengan menggunakan angkutan penyeberangan melalui sungai atau waktu tempuh Non public transport atau private car adalah tiga kali lebih lama dari

2. Penyeberangan, dengan kata lain bahwa menggunakan angkutan penyeberangan atau lebih dikenal dengan ferry transport lebih singkat waktu perjalanan dari Prajen- Palembang ilir P dengan rasio waktu per jalanan 3,07 kali. Secara ekonomis waktu yang lebih singkat akan memberikan dampak yang positif bagi para pelaku perjalanan utamanya pelaku perjalanan yang menggunakan angkutan pribadi, karena para pelaku perjalanan biasanya sifat perjalanan yang dilakukan merupakan kegiatan yang bersifat rutinitas seperti untuk bekerja , perdagangan, sekolah dan urusan-urusan yang mendukung pertumbuhan ekonomi suatu wilayah

3. Hasil analisis rasio waktu perjalanan untuk angkutan umum/public transport, dimana hasil dari perbandingan sampel pertama yang diambil adalah bernilai 2,83 atau 283 persen 
yang berarti efektifitas perjalanan yang digunakan untuk moda angkut penyeberangan lebih cepat 2,83 kali dari bila menggunakan angkutan jalan, hal ini di mungkinkan karena factor jarak yang relative lebih pendek dan factor hambatan pelayanan yang diperkirakan lebih sederhana. Untuk nilai rata rata seluruh data didapatkan nilai rasio waktu perjalanan sekitar 3,25 kali atau 325 persen dari 20 data yang disandingkan hal ini menunjukkan bahwa secara signifikan angkutan penyeberangan memang layak di operasikan secara teknis

4. Rasio biaya perjalanan ini, dikaji atas dua aspek yaitu dari sisi biaya perjalanan angkutan penyeberangan dengan angkutan public transport dan non public transport, Hal ini dibedakan karena karakter dari publik transport sangat berbeda dengan non publik transport terutama karakter pola perjalanan dan kondisi pelayanann Rasio biaya perjalanan untuk public transport yang disandingkan dengan moda angkut penyeberangan mempunyai nilai 1,33 hingga 1,57 atau rata rata nilai rasio biayanya adalah 1,38 atau bernilai 138 persen, walaupun secara kuantitatif nilai nya tidak terlalu jauh ber beda tapi yang jelas RBP> 1 atau dapat dikatakan angkutan penyeberangan atau ferry lebih hemat bila ditinjau dari biaya operasional.

5. Hasil analisa data dari private cars dengan angkutan penyeberangan yang ditinjau dari rasio biaya perjalanan ,nilai yang didapat dari hasil analisis bahwa pada sampel pertama RBP nya mencapai nilai 1,25 atau 125 persen dengan istilah ekonomi dikatakan biaya operasi untuk angkutan non public transport lebih mahal sekitar 25 persen per moda bila menggunakan lintas angkutan jalan, secara rata rata juga menghasilkan nilai yang sama persis pada setiap sampel

6. Rasio pelayanan perjalanan ini, dikaji atas dua aspek yaitu dari sisi biaya perjalanan angkutan penyeberangan dengan angkutan public transport dan non public transport, Hal ini dibedakan karena karakter dari publik transport sangat berbeda dengan non publik transport terutama karakter pola perjalanan dan kondisi pelayanannya. Rasio pelayanan perjalanan untuk public transport yang disandingkan dengan moda angkut penyeberangan mempunyai nilai 0,93 hingga 1,09 atau rata rata nilai rasio pelayanan nya adalah 1,06 atau bernilai 106 ;persen, walaupun secara kuantitatif nilai nya tidak terlalu jauh ber beda tapi yang jelas RBP> 1 atau dapat dikatakan angkutan penyeberangan atau ferry lebih baik sedikit walaupun sedikit sekali bila ditinjau dari pelayanan operasional.

7. Perbandingan pelayanan perjalanan ( RPP) antara non public transport/jalan raya dengan angkutan penyeberangan yang melalui sungai .Bahwa jumlah waktu yang didapat oleh Private cars dalam melayani penumpang dengan 20 objek observasi adalah 230 menit 
sedangkan melaui bis air dengan sampel yang sama jumlah waktu pelayanan yang di eksplorasi adalah sekitar 188 menit dan bila dibandingkan keduanya maka angkutan jalan raya mempunyai pelayanan 1,31 kali lebih lama bila dibandingkan dengan penyeberangan atau dengan kata lain penyeberangan melalui sungai lebih effisien dari Non angkot.

\subsection{REKOMENDASI}

Dari kesimpulan diatas, mengingat bahwa rasio waktu perjalanan (RWP), Rasio Pelayanan Perjalanan (RPP) dan Rasio Biaya Perjalanan (RBP) untuk angkutan penyeberangan lebih baik maka rekomendasi yang diharapkan untuk meningkatkan Standar Pelayanan transportasi di kota Palembang dan cakupannya ( Hinterland ) adalah sebagai berikut :

1. Perlunya ada pengkajian lebih lanjut untuk kelayakan teknis pengadaan kapal penyeberangan lintas Prajen-Palembang ilir (Sungai Lais) dan disertai pula dengan kajian secara financial ekonomi transport apakah itu dengan tolok ukur B/C ratio, IRR(internal rate return) maupun Net present Value (NPV) sebagai tindak lanjut kajian ini

2. Adanya penegasan kepada pihak pemerintah daerah ataupun provinsi bahwa pemberlakuan operasi angkutan sungai perlu disosialisasikan agar para investor dibidang transportasi sungai dapat memberikan sharing dalam pengusahaan angkutan sungai, dan perlu diyakinkan bahwa investasi dibidang ini lebih menjanjikan dan bila perlu berikan subsidi untuk angkutan sungai agar tarif angkutannya lebih murah dan menarik

3. Dalam penyediaan kapal baru pihak pelayaran diharapkan menyediakan pelayanan yang sesuai dengan standar pelayanan minimum guna kenyamanan yang akan diberikan kepada pengguna jasa. 


\section{DAFTAR PUSTAKA}

1. Direktorat Jendral Perhubungan darat, Pengembangan angkutan Sungai,Danau dan Penyeberangan, Jakarta 2006

2. Keputusan Menteri Perhubungan No KM 32 , Tahun 2001, Tentang Penyelenggaraan angkutan Penyeberangan.

3. Keputusan Direktur Jendral Perhubungan Darat No: SK.73/AP005/DRJD/2003 Tahun 2003, tentang Persyaratan minimal Angkutan Penyeberangan.

4. International Maritime Organization, IMO and RO RO Safety, London 1997.

5. Undang Undang Republik Indonesia Nomor 17 Tahun 2008 tentang Pelayaran

6. Nurgiyantoro, Burhan, Gunawan dan Marzuki, 2000, Statistik Terapan Untuk IlmuIlmu Sosial, Yogyakarta: Gadja Mada University Press.

7. Rakhmat, Jalaludin, 1999, Metode Penelitian Komunikasi, Bandung : PT Remaja Rosda Karya.

8. Sugiyono, 2001, Metode Penelitian Bisnis, Bandung : CV Alfabeta

9. Suharsimi, Arikanto, 2000, Manajemen Penelitian, Jakrata : Rineka Cipta

10. Bruton M.J (1985); Introduction to Transportation Planning,Hutchinson Melbourne

11. Kanafani,Adib,(1983);Transportation Demand Analysis, Mc GrawHill Book Company,New York.

12. Miro,Fidel (2005); Perencanaan Transportasi, Erlangga,Jakarta

13. Bambang.S (2009),Modelling and System Simulation:Theory,Aplication, And Sample Programs in Language C. Bandung: Imformatika.

14. Schwier., \& Misanchuk.(1994),Interactive Multimedia Instruction, London. 